\title{
EFEK NILAI KONSUMSI TERHADAP NIAT PEMBELIAN KEMBALI PADA GREEN PRODUCT
}

\author{
Yosephine Angelina Yulia \& Wisnu Untoro \\ Universitas Sebelas Maret Surakarta, Indonesia \\ Email: joeeangel5@gmail.com
}

\begin{abstract}
Abstrak: Efek Nilai Konsumsi terhadap Niat Pembelian Kembali pada Green Product. Tujuan dari penelitian ini adalah untuk menerapkan teori nilai konsumsi untuk menentukan faktor-faktor yang mempengaruhi perilaku pilihan konsumen mengenai produk ramah lingkungan, dan meneliti pengaruh nilai-nilai konsumsi seperti nilai fungsional, nilai sosial, nilai emosional, nilai kondisional, dan nilai epistemis terhadap niat membeli kembali produk ramah lingkungan. Populasi penelitian ini adalah konsumen yang menggunakan produk ramah lingkungan yang ada di kota Surakarta. Penelitian ini mengambil sampel sebanyak 100 responden secara purposive. Analisis data menggunakan analisis regresi berganda. Berdasarkan data dapat diketahui bahwa nilai konsumsi yang terdiri dari nilai fungsional, nilai sosial, nilai emosional, nilai kondisional dan nilai epistemik terbukti berpengaruh positif terhadap niat pembelian kembali pada produk ramah lingkungan.
\end{abstract}

Kata kunci: Produk ramah lingkungan, nilai konsumsi, sikap konsumen, niat pembelian kembali.

\begin{abstract}
The Effect of Consumption Values to Repurchase Intention of Green Products. This study was aimed to apply the theory of consumption values to determine the factors affecting the behavior of consumers regarding the selection of green products, and examine the influence of consumption values such as the functional value, social value, emotional value, conditional value, and epistemic value to repurchase intention of green products. The population of this research is green product customers in Surakarta city. This research selected 100 respondents purposively. Based on the data showed that the consumption values that consist of functional value, social value, emotional value, conditional value and epistemic value had a positive effect on repurchase intention of green products.
\end{abstract}

Keywords: Green product, consumption values, consumer behavior, repurchase intention.

\section{PENDAHULUAN}

Kerusakan lingkungan yang terjadi saat ini disebabkan oleh eksploitasi sumber daya alam dan konsumsi yang berlebihan dikarenakan terjadinya pertumbuhan ekonomi yang cepat. Pemanasan global, penipisan lapizan ozon dan degradasi lingkungan (tanah, udara dan air) merupakan konsekuensi yang harus ditanggung akibat kerusakan lingkungan yang dapat mengancam kesehatan dan jiwa. Saat ini, konsumen secara bertahap mengubah sikap dan perilaku mereka dalam hal konsumsi, karena kerusakan lingkungan yang sudah terjadi (Aindrila dan Mousumi, 2014). Jika pemasar dan pembuat kebijakan publik sadar untuk mengurangi perilaku negatif yang dapat merusak lingkungan, maka diperlukan sebuah pemahaman yang lebih mendalam tentang hubungan antara perilaku konsumsi 
dan perhatian akan kerusakan lingkungan. Konsumen dapat mengubah pola pembelian ke produk yang ramah lingkungan ketika kekhawatitan akan kerusakan lingkungan meningkat (Kilbourne dan Pickett, 2008).

Pada penelitian sebelumnya, keputusan konsumen untuk mengkonsumsi produk ramah lingkungan dipengaruhi oleh pendapat dari orang yang telah berpengalaman (D'Souza et al, 2007; dan Haytko dan Matulich, 2008). Konsumen juga harus membayar ekstra untuk mengkonsumsi produk yang ramah lingkungan (Chen dan Chang, 2012;. Laroche et al, 2001). Sebagai contoh, penelitian yang dilakukan di Thailand, Malaysia, dan Korea, lebih dari $80 \%$ konsumen berani membayar harga premium untuk menggunakan produk ramah lingkungan (Lung, 2010). Di Inggris, lebih dari $79 \%$ konsumen juga berani membayar harga lebih mahal untuk produk yang ramah lingkungan. (Laroche et al., 2001 dalam Norazah dan Norbayah, 2015). Perilaku konsumen sehari hari dapat dipengaruhi oleh informasi mengenai kerusakan lingkungan dan memburuknya ekosistem. Fase proses pengambilan keputusan yang dilakukan oleh konsumen juga dapat dipengaruhi oleh pengetahuan konsumen tentang konsumsi yang berdampak pada kerusakan lingkungan (Laroche et al., 2001 pada Norazah dan Norbayah, 2015). Maka, jika konsumen memakai produk yang ramah lingkungan (misalnya potensi daur ulang, polusi rendah), dapat membangkitkan emosi konsumen untuk melindungi dan menjaga lingkungan. (Norazah dan Norbayah, 2015).

Hambatan yang sering terjadi pada pangsa pasar produk ramah lingkungan adalah kurangnya informasi yang didapat oleh konsumen tentang produk ramah lingkungan sehingga mengakibatkan kesenjangan sikap perilaku antar kepedulian lingkungan dan perilaku pembelian yang sebenarnya (Ohtomo dan Hirose, 2007). Untuk memprediksi perilaku konsumen yang berkelanjutan, dilakukan riset kepada konsumen terhadap persepsi konsumen tentang produk ramah lingkungan, seperti harga dan kualitas (nilai fungsional), dorongan konsumen untuk mencari pengetahuan (nilai epistemik), pendapat rekan (nilai sosial), pengaruh kegiatan promosi dan subsidi (nilai kondisional), kepedulian akan lingkungan (nilai lingkungan) (Laroche et al., 200; Sharma dan Bagoria, 2012 pada Norazah dan Norbayah, 2015).

Niat pembelian kembali menunjukkan kesediaan individu untuk melakukan pembelian lain dari perusahaan yang sama, berdasarkan pengalaman sebelumnya (Hellier et al., 2003 dalam Cangsu et al., 2012). Dengan demikian, identifikasi faktorfaktor penentu niat pembelian kembali adalah sangat penting untuk peneliti dan praktisi. Namun, menurut Hellier et al. (2003), penelitian sebelumnya pada niat pembelian kembali pada konsumen sebagian besar telah terfragmentasi, dan beberapa studi telah menguji struktur berdasarkan kerangka diverifikasi model. Penelitian ini mencoba menjelaskan hubungan antara efek nilai-nilai konsumsi terhadap niat pembelian kembali pada produk yang ramah lingkungan.

Penelitian ini menggunakan teori nilai konsumsi untuk produk ramah lingkungan sebagai dasar teoritis untuk memverifikasi 
faktor pengaruh pada perilaku pilihan konsumen akan niat untuk membeli kembali. Teori ini menjelaskan perilaku yang dipengaruhi oleh nilai-nilai fungsional, sosial, emosional, kondisional, dan epistemik. Nilai fungsional diukur untuk persepsi konsumen tentang produk ramah lingkungan, harga dan kualitas. Nilai sosial menyangkut ukuran utilitas untuk konsumen, yang dipengaruhi oleh opini rekan. Nilai emosional adalah ukuran emosi konsumen terhadap produk ramah lingkungan. Nilai kondisional adalah ukuran dari utilitas sesuai dengan situasi tertentu. Kekhawatiran nilai epistemik mengukur kecenderungan konsumen untuk menginginkan pengetahuan dan mencari halhal baru. Oleh karena itu, teori ini dirancang untuk meningkatkan pemahaman tentang perilaku pilihan konsumen dan membantu praktisi, pembuat kebijakan, dan peneliti akademis dalam menentukan apa yang memotivasi pilihan tertentu. Pada penelitian yang telah dilakukan oleh Aindrila dan Mousumi (2014), disebutkan bahwa nilai konsumsi terbukti mempunyai pengaruh kuat pada perilaku konsumsi berkelanjutan dan menyarankan pada pemasar untuk menerapkan teori nilai konsumsi pada strategi penjualan produk ramah lingkungan. Perilaku konsumsi berkelanjutan dapat diwujudkan jika ada niat pembelian kembali pada produk yang telah dikonsumsi oleh konsumen. Jika konsumen merasa puas dengan merasakan nilai-nilai konsumsi pada produk ramah lingkungan, maka konsumen akan membeli kembali produk ramah lingkungan.

Studi menganalisis konsumen yang ramah lingkungan akan terus menarik sebagai kesadaran lingkungan yang berkembang dari waktu ke waktu, dan karena itu temuan dari setiap studi tertentu belum tentu tetap berlaku tanpa batas waktu. Penelitian baru pada produk ramah lingkungan bertujuan untuk mengidentifikasi perkembangan sikap konsumen, niat, perilaku dan keinginan untuk membeli kembali (Zeithaml, 1988 pada. Blackwell et al, 2011 pada Janine et al, 2015). Studi ini meneliti nilai-nilai konsumen dalam mengkonsumsi dan pilihan mengenai produk ramah lingkungan, dan membantu dalam memahami faktor yang mempunyai pengaruh penting pada perilaku pilihan pelanggan serta keinginan konsumen untuk membeli kembali produk ramah lingkungan setelah merasakan manfaat dan nilai yang didapat setelah menggunakan produk ramah lingkungan.

Penelitian ini dimaksudkan untuk menerapkan teori nilai konsumsi untuk menentukan faktor - faktor yang mempengaruhi pada perilaku pilihan konsumen mengenai produk ramah lingkungan, dan meneliti setelah merasakan nilai-nilai yang didapat pada produk ramah lingkungan, konsumen akan berniat membeli kembali produk ramah lingkungan. Temuan empiris yang ditawarkan membantu untuk mengkonfirmasi secara empiris, pengaruh dari faktor nilai konsumsi seperti nilai fungsional, nilai sosial, nilai emosional, nilai kondisional, dan nilai epistemik tentang niat untuk membeli kembali konsumen akan produk ramah lingkungan.

Berdasar uraian pada latar belakang masalah di atas, maka peneliti bermaksud untuk melakukan penelitian tentang: "Efek Nilai Konsumsi terhadap Niat pembelian Kembali pada Green Product." 


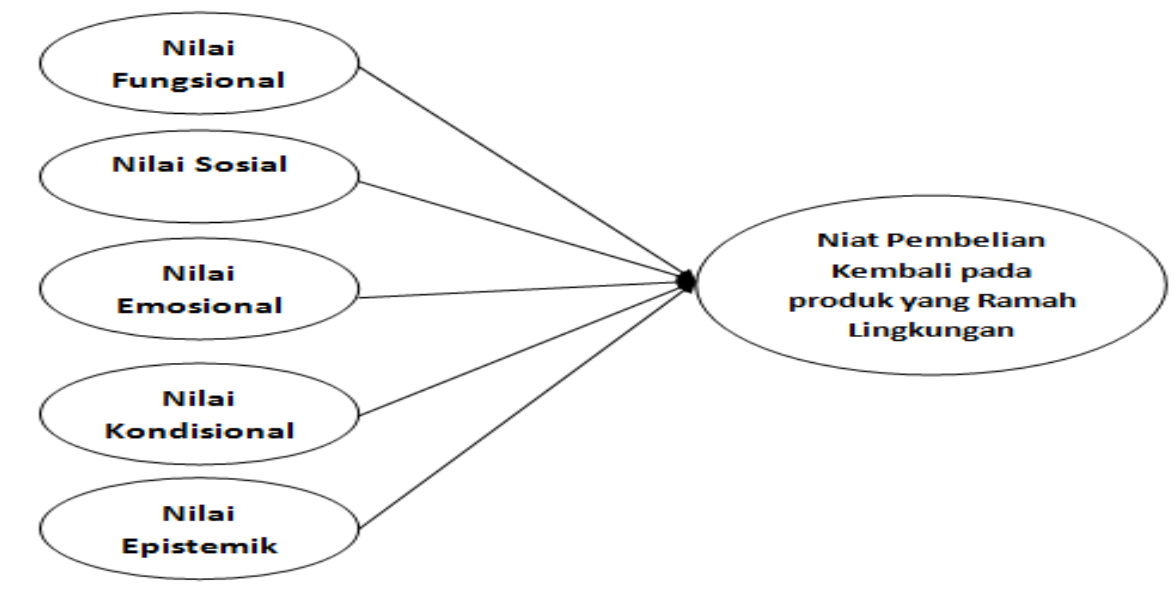

Gambar 1. Kerangka Pemikiran

\section{METODE}

Penelitian ini dikategorikan sebagai penelitian survey. Penelitian ini dilaksanakan di Wilayah Surakarta. Variabel yang digunakan dalam penelitian ini adalah nilai fungsional, nilai sosial, nilai emosional, nilai kondisional, nilai epistemik dan niat pembelian kembali. Kerangka pemikiran penelitian yang tertuang dalam gambar 1 merupakan modifikasi dari model penelitian Norazah dan Norbayah (2015); Selim et al. (2013).

Berdasarkan dugaan sementara bahwa nilai fungsional kualitas berpengaruh pada niat pembelian kembali (Sweeney dan Soutar, 2001 ; Ha et al., 2010; Green, 2005; Jayawardhena dan Wright, 2009; Harris dan Goode, 2010). Nilai fungsional harga berpengaruh pada niat pembelian kembali (Sweeney dan Soutar, 2001 ; Ha et al., 2010; Green, 2005; Jayawardhena dan Wright, 2009; Harris dan Goode, 2010). Nilai sosial berpengaruh pada niat pembelian kembali (Sweeney dan Soutar, 2001 ; Ha et al., 2010; Green, 2005; Jayawardhena dan Wright, 2009; Harris dan Goode, 2010). Nilai emosional berpengaruh pada niat pembelian kembali (Arvolla et al., 2008; Ha et al., 2010; Green, 2005; Jayawardhena dan Wright, 2009; Harris dan Goode, 2010). Nilai kondisional berpengaruh pada niat pembelian kembali (Dholakia, 2001 ; Ha et al., 2010; Green, 2005; Jayawardhena dan Wright, 2009; Harris dan Goode, 2010). Nilai epistemik berpengaruh pada niat pembelian kembali (Hirschman, 1980 ; Ha et al., 2010; Green, 2005; Jayawardhena dan Wright, 2009; Harris dan Goode, 2010), maka hipotesis yang diajukan dalam penelitian ini adalah sebagai berikut:

1. H1a: Nilai fungsional kualitas berpengaruh signifikan terhadap niat konsumen untuk membeli kembali produk yang ramah lingkungan

2. H1b: Nilai fungsional harga berpengaruh signifikan terhadap niat konsumen untuk membeli kembali produk yang ramah lingkungan

3. H2: Nilai sosial berpengaruh signifikan terhadap niat konsumen untuk membeli kembali produk yang ramah lingkungan

4. H3: Nilai emosional berpengaruh signifikan terhadap niat konsumen untuk membeli kembali produk yang ramah lingkungan 
Tabel 1. Ringkasan Skala Pengukuran

\begin{tabular}{|c|c|}
\hline Variabel & Item Pertanyaan \\
\hline $\begin{array}{l}\text { Nilai Fungsional-Kualitas } \\
\text { diadaptasi dari Sweeney } \\
\text { dan Soutar (2001) pada } \\
\text { Norazah dan Norbayah } \\
(2015)\end{array}$ & $\begin{array}{l}\cdot \text { Produk ramah lingkungan mempunyai kualitas yang konsisten / tidak berubah } \bullet \\
\text { Produk ramah lingkungan dibuat dengan baik } \bullet \text { Produk ramah lingkungan memiliki } \\
\text { standar kualitas yang baik } \bullet \text { Produk ramah lingkungan akan menggunakan kualitas } \\
\text { secara konsisten }\end{array}$ \\
\hline $\begin{array}{l}\text { Nilai Fungsional-Harga } \\
\text { diadaptasi dari Sweeney } \\
\text { dan Soutar (2001) pada } \\
\text { Norazah dan Norbayah } \\
(2015)\end{array}$ & $\begin{array}{l}\cdot \text { Produk ramah lingkungan mempunyai harga yang masuk akal } \bullet \text { Produk ramah } \\
\text { lingkungan memberikan nilai terhadap uang } \bullet \text { Produk ramah lingkungan adalah } \\
\text { produk yang bagus untuk harga yang diberikan } \bullet \text { Produk ramah lingkungan ekonomis }\end{array}$ \\
\hline $\begin{array}{l}\text { Nilai Sosial diadaptasi dari } \\
\text { Sweeney dan Soutar }(2001) \\
\text { pada Norazah dan } \\
\text { Norbayah }(2015)\end{array}$ & $\begin{array}{l}\text { Membeli produk ramah lingkungan akan membantu saya merasa diterima } \\
\text { Membeli produk ramah lingkungan akan meningkatkan nilai yang saya rasakan } \\
\text { Membeli produk ramah lingkungan akan memberikan pengaruh yang baik bagi orang } \\
\text { lain } • \text { Membeli produk ramah lingkungan akan memberikan penerimaan sosial }\end{array}$ \\
\hline $\begin{array}{l}\text { Nilai Emosional diadaptasi } \\
\text { dari Arvola et al (2008) } \\
\text { pada Norazah dan } \\
\text { Norbayah (2015) }\end{array}$ & $\begin{array}{l}\cdot \text { Membeli produk ramah lingkungan yang bukan produk konvensional akan } \\
\text { memberikan kontribusi pribadi ke arah yang lebih baik } \bullet \text { Membeli produk ramah } \\
\text { lingkungan yang bukan produk konvensional akan memberikan perasaan yang benar } \\
\text { secara moral } \bullet \text { Membeli produk ramah lingkungan yang bukan produk ramah } \\
\text { lingkungan akan membuat saya merasa menjadi orang yang lebih baik }\end{array}$ \\
\hline $\begin{array}{l}\text { Nilai Kondisional } \\
\text { diadaptasi dari Dholakia } \\
\text { (2001) pada Norazah dan } \\
\text { Norbayah (2015) }\end{array}$ & $\begin{array}{l}\text { - Saya akan membeli produk ramah lingkungan yang bukan produk konvensional } \\
\text { pada saat keadaan lingkungan memburuk } \bullet \text { Saya akan membeli produk ramah } \\
\text { lingkungan yang bukan produk konvensional ketika ada subsidi untuk produk ramah } \\
\text { lingkungan } • \text { Saya akan membeli produk ramah lingkungan yang bukan produk } \\
\text { konvensional ketika ada promosi atau diskon pada produk ramah lingkungan } \bullet \text { Saya } \\
\text { akan membeli } \\
\text { produk ramah lingkungan yang bukan produk konvensional ketika produk ramah } \\
\text { lingkungan tersedia }\end{array}$ \\
\hline $\begin{array}{l}\text { Nilai Epistemik diadaptasi } \\
\text { dari Hirschman (1980) pada } \\
\text { Norazah dan Norbayah } \\
(2015)\end{array}$ & $\begin{array}{l}\text { - Sebelum membeli produk, saya akan memperoleh informasi penting tentang aneka } \\
\text { pembuatan dan model produk } \bullet \text { Saya akan memperoleh banyak informasi tentang } \\
\text { aneka pembuatan dan model produk } \bullet \text { Saya bersedia untuk mencari informasi baru } \bullet \\
\text { Saya akan mencari informasi produk yang berbeda dan yang baru }\end{array}$ \\
\hline $\begin{array}{l}\text { Niat pembelian Kembali } \\
\text { diadaptasi dari Ha } \text { et al. } \\
\text { (2010), Green (2005), } \\
\text { Jayawardhena (2009), } \\
\text { Harris (2010) pada Selim } \\
\text { Aren et al. (2013) }\end{array}$ & $\begin{array}{l}\text { 1 Saya mempertimbangkan bahwa produk ramah lingkungan menjadi pilihan pertama } \\
\text { saya } 2 \text {. Saya akan menggunakan produk ramah lingkungan lagi di masa yang akan } \\
\text { datang } 3 \text {. Dengan perubahan lingkungan saat ini, saya berniat untuk menggunakan } \\
\text { produk ramah lingkungan } 4 \text {. Saya akan membeli kembali produk ramah lingkungan } \\
\text { 5. Dengan perubahan lingkungan saat ini, saya mempertimbangkan bahwa saya harus } \\
\text { menggunakan produk ramah lingkungan untuk masa yang akan datang }\end{array}$ \\
\hline
\end{tabular}

5. H4: Nilai kondisional berpengaruh signifikan terhadap niat konsumen untuk membeli kembali produk yang ramah lingkungan

6. H5: Nilai epistemik berpengaruh signifikan terhadap niat konsumen untuk membeli kembali produk yang ramah lingkungan

Populasi penelitian ini adalah konsumen yang menggunakan produk ramah lingkungan yang ada di kota Surakarta. Seperti diketahui bahwa kota Surakarta merupakan salah satu kota besar di Indonesia dimana kesadaran konsumen dalam menggunakan produk ramah lingkungan lebih tinggi daripada di daerah. Kota Solo juga menjadi salah satu kota inklusi untuk anak berkebutuhan khusus, dimana konsumsi makanan bagi anak berkebutuhan khusus harus bebas pengawet dan bebas SMG sehingga tingkat kebutuhan akan makanan organik juga tinggi. Oleh karena itu, populasi ini merupakan populasi yang tidak terbatas karena tidak dapat diketahui secara pasti jumlah konsumen yang menggunakan produk ramah lingkungan yang ada di kota Surakarta. 
Jurnal Economia, Volume 12, Nomor 1, April 2016

Tabel 2. Hasil Confirmatory Factor Analysis (CFA)

\begin{tabular}{lccc}
\hline Variabel & Item & Factor Loading & Keterangan \\
\hline Nilai Fungsional Kualitas & X1 & 0,713 & Valid \\
& X2 & 0,808 & Valid \\
& X3 & 0,838 & Valid \\
X4 & 0,841 & Valid \\
\hline Nilai Fungsional harga & X1 & 0,861 & Valid \\
& X2 & 0,801 & Valid \\
& X3 & 0,828 & Valid \\
& X4 & 0,773 & Valid \\
\hline Nilai Sosial & X1 & 0,913 & Valid \\
& X2 & 0,714 & Valid \\
& X3 & 0,630 & Valid \\
& X4 & 0,701 & Valid \\
\hline Nilai Emosional & X1 & 0,881 & Valid \\
& X2 & 0,895 & Valid \\
X3 & 0,815 & Valid \\
\hline Nilai Kondisional & X1 & 0,746 & Valid \\
& X2 & 0,649 & Valid \\
& X3 & 0,909 & Valid \\
& X4 & 0,878 & Valid \\
\hline Nilai Epistemik & X1 & 0,744 & Valid \\
& X2 & 0,876 & Valid \\
& X3 & 0,845 & Valid \\
X4 & 0,893 & Valid \\
\hline Niat Pembelian Kembali & X1 & 0,740 & Valid \\
& X2 & 0,767 & Valid \\
& X3 & 0,602 & Valid \\
X4 & 0,783 & Valid \\
& X5 & 0,749 & Valid \\
\hline
\end{tabular}

Dalam penelitian ini jumlah populasinya belum diketahui. Sampel adalah bagian dari populasi yang karakteristiknya hendak diselidiki dan dianggap mewakili keseluruhan populasi. Metode penentuan sampel yang digunakan dalam penelitian ini menggunakan salah satu teknik non probability sampling, yaitu dengan metode purposive sampling. Pertimbangan yang dipergunakan dalam penelitian ini yaitu responden berusia 17 tahun ke atas, merupakan influencer/decider dalam proses pembelian produk ramah lingkungan.

Jumlah konsumen yang menggunakan produk ramah lingkungan belum diketahui sehingga dalam menentukan jumlah sampel dalam penelitian ini, digunakan rumus
(Supramono, 2003:62). Berdasarkan rumus tersebut jumlah minimal sampel adalah 96, sehingga penelitian ini mengambil sampel sebanyak 100 responden. Instrumen penelitian untuk pengumpulan data dalam penelitian ini menggunakan kuesioner. Ringkasan item dari skala pengukuran akan disajikan pada Tabel 1.

Uji instrumen penelitian meliputi uji validitas dan uji reliabilitas. Uji validitas menggunakan teknik Confirmatory Factor Analysis (CFA) dengan bantuan SPSS versi 16 . Setiap item factor pertanyaan harus memiliki nilai Kaiser-Meyer-Olkin Measure of Sampling Adequancy (KMOS MSA) > 0,50. Item pertanyaan dikatakan valid jika memiliki factor loading $\geq 0,50$ dan telah terekstrak 
Tabel 3. Hasil Uji Reliabilitas

\begin{tabular}{lcc}
\hline \multicolumn{1}{c}{ Variabel } & Cronbach's Alpha & Status \\
\hline Nilai Fungsional - Kualitas & 0,854 & Reliabel \\
\hline Nilai Fungsional - Harga & 0,869 & Reliabel \\
\hline Nilai Sosial & 0,765 & Reliabel \\
\hline Nilai Emosional & 0,881 & Reliabel \\
\hline Nilai Kondisional & 0,830 & Reliabel \\
\hline Nilai Epistemik & 0,930 & Reliabel \\
\hline Niat Pembelian Kembali & 0,836 & Reliabel \\
\hline
\end{tabular}

sempurna (Ghozali, 2006). Untuk mengukur reliabilitas, peneliti menggunakan alat ukur Cronbach Alpha. Hasil pengujian hipotesis menggunakan regresi linear berganda, untuk mengetahui apakah nilai konsumsi berpengaruh positif terhadap niat pembelian kembali.

\section{HASIL DAN PEMBAHASAN}

\section{Uji Validitas}

Hasil pengujian disajikan dalam bentuk Tabel. Uji validitas dalam penelitian ini juga menggunakan uji rotated component matrix untuk mengetahui validitas dari masingmasing item. Pada Tabel 2 menunjukkan bahwa semua item telah terekstrak sempurna, dengan nilai factor loading $>0,5$ sehingga dapat disimpulkan bahwa semua item pertanyaan dalam penelitian ini valid.

\section{Uji Reliabilitas}

Variabel dikatakan reliabel jika nilai Cronbach Alpha pada variabel tersebut bernilai lebih dari 0,6. Tabel 3 menunjukkan bahwa nilai Cronbach Alpha dari semua variabel pada penelitian ini bernilai lebih dari 0,6, sehingga dapat dinyatakan reliabilitas untuk instrumen pada pernyataan dari variabel nilai fungsional-kualitas, nilai fungsionalharga, nilai sosial, nilai emosional, nilai kondisional, nilai epistemic, dan niat pembelian kembali dinyatakan reliabel.

\section{Pengujian Hipotesis}

Uji Koefisien determinasi $\left(R^{2}\right)$ dilakukan untuk mengetahui berapa besarnya hubungan dari variabel independen: nilai fungsional-kualitas, nilai fungsional-harga, nilai sosial, nilai emosional, nilai kondisional, nilai epistemik dengan variabel dependen: niat pembelian kembali. Untuk regresi dengan lebih dari dua variabel independen digunakan adjusted $\mathrm{R}^{2}$ sebagai koefisien determinasi yang disajikan dalam tabel 4 .

Tabel 4 Hasil Uji $\mathrm{R}^{2}$ dan Adjusted $\mathrm{R}^{2}$

\begin{tabular}{|c|c|}
\hline R Square & Adjusted R Square \\
\hline 0,403 & 0,364 \\
\hline
\end{tabular}

Dari hasil uji regresi diatas diketahui pada model regresi diperoleh nilai Adjusted $\mathrm{R}^{2}$ sebesar 0,364, yang berartu variasi pada variabel independen (nilai fungsionalkualitas, nilai fungsional-harga, nilai sosial, nilai emosional, nilai kondisional, nilai epistemik) dapat menjelaskan variasi pada variabel dependennya yaitu niat pembelian kembali sebesar $36,4 \%(0,364 \times 100 \%)$, sedangkan sisanya $(100 \%-36,4 \%=63,6 \%)$ dapat dijelaskan oleh faktor-faktor lain yang tidak diikutsertakan dalam model regresi. 
Tabel 5. Hasil Pengujian Hipotesis

\begin{tabular}{lccc}
\hline \multirow{2}{*}{ Variabel Independen } & \multicolumn{3}{c}{ Variabel Dependen } \\
\cline { 2 - 4 } & Beta & $\mathrm{T}$ & Sig. \\
\cline { 2 - 4 } & 0,212 & 2,325 & 0,000 \\
\hline Nilai Fungsional-Kualitas (NFK) & 0,246 & 2,815 & 0,000 \\
Nilai Fungsional Harga (NFH) & 0,187 & 2,221 & 0,000 \\
Nilai Sosial (NS) & 0,186 & 2,107 & 0,000 \\
Nilai Emosional (NEM) & 0,205 & 2,360 & 0,000 \\
Nilai Kondisional (NK) & 0,446 & 5,088 & 0,000 \\
Nilai Epistemik (NEP) & & & \\
\hline
\end{tabular}

Dalam penelitian ini terdapat 5 variabel independen, yaitu: nilai fungsional, nilai sosial, nilai emosional, nilai kondisional dan nilai epistemik. Untuk nilai fungsional dibagi menjadi dua yaitu : nilai fungsional kualitas dan nilai fungsional harga. Variabel independen tersebut akan diujikan bagaimana hubungan dan pengaruhnya terhadap 1 variabel dependen, yaitu: niat pembelian kembali. Hasil uji hipotesis dari lima hipotesis yang diajukan dalam penelitian ini terangkum secara ringkas dalam Tabel 5.

\section{Pengaruh Nilai Fungsional - Kualitas Pada Niat pembelian kembali Produk Ramah \\ Lingkungan}

Berdasarkan Tabel 5 diketahui bahwa nilai signifikansi dari nilai fungsional-kualitas sebesar $0,000<0,05$ maka diambil kesimpulan bahwa nilai fungsional - kualitas secara signifikan mempengaruhi niat pembelian kembali produk ramah lingkungan dengan hubungan yang positif, yang berarti semakin tinggi nilai fungsional - kualitas berpengaruh positif dengan tingginya niat pembelian kembali produk ramah lingkungan. Dengan demikian hipotesis yang menyatakan pengaruh nilai fungsional - kualitas mempunyai efek positif pada niat pembelian kembali produk ramah lingkungan didukung. Hasil hipotesis mendukung hasil penelitian terdahulu yang dilakukan oleh Aindrila dan Mousumi (2014) yang menyatakan bahwa nilai fungsional kualitas berpengaruh positif terhadap perilaku konsumsi berkelanjutan. Konsumen yang ramah lingkungan sadar lebih memilih untuk membeli produk ekologi yang menggunakan bahan alam untuk kosmetik, produk kayu dari hutan lestari, sayuran organik, aerosol ramah ozon, tidak diuji pada hewan (Norazah, 2015). Dengan demikian dapat dipahami bahwa konsumen mempertimbangkan kualitas untuk mempengaruhi keputusan untuk membeli dan membeli kembali pada produk yang ramah lingkungan.

\section{Pengaruh Nilai Fungsional - Harga Pada Niat pembelian Kembali Produk Ramah Lingkungan}

Berdasarkan Tabel 5 diketahui bahwa nilai signifikansi dari nilai fungsional-kualitas sebesar $0,000<0,05$ maka diambil kesimpulan bahwa nilai fungsional - harga secara signifikan mempengaruhi niat pembelian kembali produk ramah lingkungan 
dengan hubungan yang positif, yang berarti semakin tinggi nilai fungsional - harga berpengaruh positif dengan tingginya niat pembelian kembali produk ramah lingkungan. Dengan demikian hipotesis yang menyatakan pengaruh nilai fungsional harga mempunyai efek positif pada niat pembelian kembali produk ramah lingkungan didukung. Hasil hipotesis mendukung hasil penelitian terdahulu yang dilakukan oleh Aindrila dan Mousumi (2014) yang menyatakan bahwa nilai fungsional harga berpengaruh positif terhadap perilaku konsumsi berkelanjutan. Akhirnya telah ada kenaikan jumlah konsumen di negara-negara maju yang mengambil langkah-langkah substantif untuk mengurangi degradasi lingkungan dan setuju untuk membayar harga premium untuk produk ramah lingkungan (Laroche et al., 2001). Dengan demikian dapat dipahami bahwa konsumen mempertimbangkan harga untuk mempengaruhi keputusan untuk membeli dan membeli kembali pada produk yang ramah lingkungan.

\section{Pengaruh Nilai Sosial Pada Niat pembelian Kembali Produk Ramah lingkungan}

Berdasarkan Tabel 5 diketahui bahwa nilai signifikansi dari nilai sosial sebesar 0,000 < 0,05 dan maka diambil kesimpulan bahwa nilai sosial secara signifikan mempengaruhi niat pembelian kembali produk ramah lingkungan dengan hubungan yang positif, yang berarti semakin tinggi nilai sosial berpengaruh positif dengan tingginya niat pembelian kembali produk ramah lingkungan. Dengan demikian hipotesis yang menyatakan pengaruh nilai sosial mempunyai efek positif pada niat pembelian kembali produk ramah lingkungan didukung. Hasil hipotesis mendukung hasil penelitian terdahulu yang dilakukan oleh Aindrila dan Mousumi (2014) yang menyatakan bahwa nilai sosial berpengaruh positif terhadap perilaku konsumsi berkelanjutan. Nilai sosial memegang peranan penting dalam konsumsi berkelanjutan yang nantinya mengarah kepada niat pembelian kembali pada produk ramah lingkungan, dimana pendapat ahli maupun orang lain memberikan kontribusi yang besar juga terhadap produk ramah lingkungan.

\section{Pengaruh Nilai Emosional Pada Niat pembelian Kembali Produk Ramah \\ lingkungan}

Berdasarkan Tabel 5 diketahui bahwa nilai signifikansi dari nilai emosional sebesar $0,000<0,05$ maka diambil kesimpulan bahwa nilai emosional secara signifikan mempengaruhi niat pembelian kembali produk ramah lingkungan dengan hubungan yang positif, yang berarti semakin tinggi nilai emosional berpengaruh positif dengan tingginya niat pembelian kembali produk ramah lingkungan. Dengan demikian hipotesis yang menyatakan pengaruh nilai emosional mempunyai efek positif pada niat pembelian kembali produk ramah lingkungan didukung. Hasil hipotesis mendukung hasil penelitian terdahulu yang dilakukan oleh Aindrila dan Mousumi (2014) yang menyatakan bahwa nilai emosional berpengaruh positif terhadap perilaku konsumsi berkelanjutan. Konsumen dengan nilai-nilai emosional yang positif melakukan pembelian ramah lingkungan dirasa menyenangkan dan membuat keyakinan mereka berperilaku secara bertanggung 
jawab dengan melindungi lingkungan (Lin dan Huang, 2012; Rex dan Baumann, 2007). Bei dan Simpson (1995) menemukan bahwa sebagian besar responden $(89,1 \%)$ merasa bahwa mereka menyelamatkan lingkungan ketika mereka membeli produk daur ulang. Oleh karena itu, nilai emosional yang dirasakan dan didapatkan konsumen dalam mengkonsumsi produk ramah lingkungan sangat berpengaruh pada niat pembelian kembali pada produk ramah lingkungan.

\section{Pengaruh Nilai Kondisional Pada Niat pembelian Kembali Produk Ramah}

\section{Lingkungan}

Berdasarkan Tabel 5 diketahui bahwa nilai signifikansi dari nilai kondisional sebesar 0,000<0,05 maka diambil kesimpulan bahwa nilai kondisional secara signifikan mempengaruhi niat pembelian kembali produk ramah lingkungan dengan hubungan yang positif, yang berarti semakin tinggi nilai kondisional berpengaruh positif dengan tingginya niat pembelian kembali produk ramah lingkungan. Dengan demikian hipotesis yang menyatakan pengaruh nilai kondisional mempunyai efek positif pada niat pembelian kembali produk ramah lingkungan didukung. Hasil hipotesis mendukung hasil penelitian terdahulu yang dilakukan oleh Aindrila dan Mousumi (2014) yang menyatakan bahwa nilai kondisional berpengaruh positif terhadap perilaku konsumsi berkelanjutan. Atribut, yang memiliki efek pada perilaku saat ini.Variabel situasional mengacu pada keadaan sekitar individu karena mereka menanggapi rangsangan berkaitan dengan kebutuhan dan keinginan mereka (Nicholls et al., 1996). Ketika situasi pribadi, yaitu, variabel situasional konsumen, mengalami perubahan, perilaku pembelian konsumen dapat dipengaruhi (Laaksonen, 1993). Lin dan Huang (2012) menemukan bahwa nilai kondisional mempengaruhi perilaku konsumen dalam memilih dan konsumen mencatat tentang konsekuensi lingkungan selama pengambilan keputusan dalam membeli. Berdasarkan diskusi diatas, dapat disimpulkan bahwa nilai kondisonal mempunyai pengaruh terhadap adopsi produk ramah lingkungan dan konsumsi berkelanjutan, sehingga nilai kondisional memberikan pengaruh positif terhadap niat pembelian kembali pada produk ramah lingkungan.

\section{Pengaruh Nilai Epistemik Pada Niat pembelian Kembali Produk Ramah \\ Lingkungan}

Berdasarkan Tabel 5 diketahui bahwa nilai signifikansi dari nilai emosional sebesar $0,000<0,05$ maka diambil kesimpulan bahwa nilai emosional secara signifikan mempengaruhi niat pembelian kembali produk ramah lingkungan dengan hubungan yang positif, yang berarti semakin tinggi nilai emosional berpengaruh positif dengan tingginya niat pembelian kembali produk ramah lingkungan. Dengan demikian hipotesis yang menyatakan pengaruh nilai epistemik mempunyai efek positif pada niat pembelian kembali produk ramah lingkungan didukung. Hasil hipotesis mendukung hasil penelitian terdahulu yang dilakukan oleh Aindrila dan Mousumi (2014) yang menyatakan bahwa nilai epistemik berpengaruh positif terhadap perilaku konsumsi berkelanjutan. Nilai epistemik pada penelitian sebelumnya telah 
menegaskan adalah prediktor utama perilaku konsumsi yang ramah lingkungan (Biswas dan Roy, 2015). Pengetahuan lingkungan ini secara signifikan memberi kecenderungan akan perilaku yang ramah lingkungan dan mempromosikan sikap yang menguntungkan terhadap konsumsi produk ramah lingkungan. Jika konsumen ingin terus mengkonsumsi produk ramah lingkungan, maka niat untuk membeli kembali produk hijau juga sangat besar.

Hasil penelitian ini menunjukkan bahwa konsumen dengan rentang usia 26 tahun ke atas merupakan peluang yang menjanjikan untuk memasarkan produk ramah lingkungan, terutama konsumen perempuan, karena dalam rentang usia ini konsumen dianggap sudah memiliki pengetahuan yang cukup mengenai lingkungan dan produk ramah lingkungan, memiliki idealism yang kuat, serta sudah mulai membangun kemandirian finansialnya. Dalam mengaplikasikan hasil penelitian ini ke dalam perencanaan pemasaran, para pemasar produk ramah lingkungan disarankan untuk mempertimbangkan menggabungkan nilai-nilai konsumsi seperti nilai fungsional, nilai sosial, nilai emosional, nilai kondisional, dan nilai epistemik yang terkait dengan green marketing.

Pemasar produk ramah lingkungan harus memperhatikan tentang konsumen yang membeli produk ramah lingkungan dengan harga yang lebih tinggi dari produk konvensional harus sesuai dengan kualitas yang didapat serta manfaat kesadaran lingkungan karena menggunakan produk yang ramah lingkungan. Pemasar produk ramah lingkungan juga harus bisa mengidentifikasi dan menarget para pemimpin opini (opinion leader) atau pendapat para ahli di dalam lingkup teman sesasama (peer group). Dengan menggunakan strategi menyebarkan testimonial positif atau word-of-mouth yang positif mengenai produk ramah lingkungan kepada teman-teman mereka baik secara langsung maupun melalui social media. Dengan adadnya referensi yang baik dari pendapat ahli ataupun dari teman akan memberikan pilihan bagi konsumen untuk mengkonsumsi produk ramah lingkungan dan memperkuat kepedulian lingkungan.

Pesan-pesan terkait green marketing dan environmental marketing yang ditujukan kepada konsumen sebaiknya menggunakan unsure-unsur emosional yang sifatnya berupa ajakan tentang kepedulian lingkungan. Seperti menggunakan kalimatkalimat yang mengandung ide positif seperti "mari selamatkan bumi", "save water for live", "hijaukan kembali untuk masa depan bumi kita" sebaiknya dimasukkan ke dalam pesan-pesan yang akan disampaikan pada kampanye produk ramah lingkungan.

Pemasar produk ramah lingkungan dapat meningkatkan konsumsi konsumen melalui promosi dan diskon untuk mendorong pembelian produk ramah lingkungan. Pada saat yang sama, pemasar juga harus menunjukkan tanggung jawab sosial perusahaan mereka dengan merangkul operasi hijau dalam semua aspek produksi mereka, sehingga produk yang telah diproduksi ramah lingkungan dalam hal memproduksi, mempromosikan, dan kemasan produk.

Hasil penelitian ini juga meningkatkan kesadaran pengetahuan pemasar produk ramah lingkungan, dan memungkinkan 
pemasar untuk mempromosikan manfaat menggunakan produk ramah lingkungan kepada konsumen, sehingga mendorong konsumen untuk memilih produk ramah lingkungan sebagai bagian dari gaya hidup sehari-hari mereka, dan kemudian mengurangi eksploitasi sumber daya alam dan memajukan ideal hidup ramah lingkungan. Tentu saja, pemasar harus memikul tanggung jawab untuk membantu membangkitkan kesadaran publik yang positif tentang perlunya produk yang ramah lingkungan.

\section{SIMPULAN}

Penelitian yang dilakukan ini bertujuan untuk menerapkan teori nilai konsumsi untuk menentukan faktor - faktor yang mempengaruhi pada perilaku pilihan konsumen mengenai produk ramah lingkungan, dan meneliti setelah merasakan nilai-nilai yang didapat pada produk ramah lingkungan, konsumen akan berniat membeli kembali produk ramah lingkungan. Dalam hal ini peneliti menguji kelima variabel independen, yaitu: nilai fungsional, nilai sosial, nilai emosional, nilai kondisional, dan nilai epistemik untuk mengetahui variabel apa saja yang berpengaruh secara signifikan terhadap variabel dependen yaitu niat membeli kembali pada produk ramah lingkungan.

Penelitian ini memiliki beberapa keterbatasan dalam pelaksanaannya, sehingga berpengaruh terhadap hasil penelitian yang diperoleh secara keseluruhan. Adapun keterbatasan yang terdapat pada penelitian ini adalah:

1. Penelitian ini hanya dilakukan pada responden yang berdomisili di Surakarta saja. Akan lebih baik lagi jika penelitian dilakukan pada kota-kota besar lainnya sehingga hasil penelitian serta pembahasan dapat lebih beragam. Selanjutnya perbandingan hasil dari setiap kota akan mencerminkan gambaran yang lebih luas atass perilaku pembelian produk ramah lingkungan.

2. Produk ramah lingkungan/green product dan green marketing merupakan isu yang tergolong baru, sehingga pengetahuan dan pemahaman konsumen tentang produk ramah lingkungan belum terlalu dalam seperti halnya konsumen memahami produk konvensional yang sudah banyak ditemukan di pasar. Hal ini menyebabkan adanya kemungkinan bahwa konsumen memiliki keterbatasan pengetahuan dalam mendefinisikan produk apa saja yang tergolong dalam produk ramah lingkungan.

3. Penelitian ini hanya menggunakan lima variabel independen yaitu nilai fungsional, nilai sosial, nilai emosional, nilai kondisional, daan nilai epistemik yang berpengaruh terhadap niat pembelian kembali pada produk ramah lingkungan. Sehingga apabila ada variabel lain yang mempengaruhi niat pembelian kembali pada produk ramah lingkungan, maka dianggap konstan.

Mengacu pada penelitian di atas, saran yang dapat diberikan peneliti berikan kepada peneliti lain yang akan melakukan penelitian serupa adalah berdasarkan keterbatasan dan hasil yang diperoleh dari penelitian ini, yaitu sebagai berikut:

1. Penelitian hendaknya dilakukan pada kota - kota besar lainnya, karena karakteristik masyarakat di kota - kota 
besar bersifat heterogen, sehingga dalam membuat generalisasi hasil penelitian berdasarkan pada aspek - aspek yang lebih luas.

2. Penggunaan model penelitian dapat dikombinasikan dengan penelitian lain yang juga berhubungan dengan perilaku pembelian produk ramah lingkungan dan juga dapat ditambahkan variabel lain seperti variabel mediasi kepuasan yang dapat mempengaruhi perilaku membeli kembali atau tidak pada produk ramah lingkungan. Dengan demikinan, diharapkan hasil dan pembahasan penelitian dapat lebih mendalam.

\section{DAFTAR PUSTAKA}

Anderson, R. E. and Srinivasan, S. S. (2003). ESatisfaction and E-loyalty: A Contigency Framework, Journal of Psychology and Marketing, 20, 123-138.

Andrila, Biswas. And Mousumi, Roy. (2015). Green products: an exploratory study on the consumer behaviour in emerging economies of the East. Journal of Cleaner Production, 87, 463-468. .

Assael, H. (2004). Consumer Behavior: A Strategic Approach. USA: Houghton Mifflin Company

Bei, L., Simpson, E., (1995). The determinants of consumers' purchase decisions for recycled products: an application of acquisition-transaction utility theory. Advances in Consumer Research 22 (1), 257-261.

Bryman, A. \& Bell, E. (2011). Business research methods. (3 ed). Oxford: Oxford University Press.

Chen, T.B. dan Chai, L.T, (2010). Attitude towards the environment and green products. Management Science and Engineering. 4(2), 27-39.
Chen, YS, Chang CH. (2012). Enhance green purchase intentions: the roles of green perceived value, green perceived risk, and green trust. Manag Dec 2012, 50(3), 502-20.

Chen, Y. \& Chang, C. (2013). Greenwash and Green Trust: The Mediation Effects of Green Consumer Confusion and Green Perceived Risk. Journal of Business Ethics, 114 (3), 489-500.

D’Souza, C., Taghian, M., Peretiatko, R., (2007). Green decisions: demographics and consumer understanding of environmental labels. International Journal of Consumer Studies, 31 (4), 371376.

Ghauri, P. \& Grønhaug, K. (2010). Research Methods in Business Studies. (4 ed). Harlow: Pearson Education.

Haytko DL, Matulich E. (2008). Green advertising and environmentally responsible consumer behaviours: Linkages examined. J Manag Mark Res, 7(1), 2-11.

Hicks, J.M., T.J. Page, Jr., B.K. Behe, J.H. Dennis, and R.T. Fernandez. (2005). Delighted Consumers Buy Again, Journal of Consumer Satisfaction, Dissatisfaction and Complaining Behavior, 18, 94-104.

Killbourne, W., Picket, G., (2008). How materialism affects environmental belief, concern and environmentally responsible behavior. J. Bus. Res, 61, 885-893

Laroche M, Bergeron J, Barbaro-Forleo G. (2001). Targeting consumers who are willing to pay more for environmentally friendly products. Journal of Consumer Marketing, 18(6), 503-520.

Lee, J., J. Lee, and L. Feick. (2001). The Impact of Switching Costs on The Customer Satisfaction-Loyalty Link: Mobile Phone Service in France. Journal of Services Marketing, 15(1), 35-48. 
Malhotra, N.K. (2010). Marketin research: An applied orientation. New Jersey: Pearson Education.

Norazah, Mohd Suki. And Norbayah, Mohd Suki. (2016). Consumer Environmental Concern and Green Product Purchase in Malaysia: Structural Effects of Consumption Values. Journal of Cleaner Production. 132, 204-214.

Rettie, R., Burchell, K. \& Riley, D. (2012). Normalising green behaviours: A new approach to sustainability marketing. Journal of Marketing Management, 28 (3-4), 420-444.
Shamsadhani, P., Chon-Lin, G. dan Richmond, D. (1993). Exploring green consumers in an oriental culture: Role of personal and marketing mix. Advances in consumer research, 20, 488-493.

Wang, P., Qian, L., Yu, Qi., (2013). Factors Influencing sustainable consumption behaviors; a study of rural residences in China, Journal of Cleaner Production, 63, 152-165.

Wells, V.K., Ponting, C.A. \& Peattie, K. (2011). Behaviour and climate change: Consumer perceptions of responsibility. Journal of Marketing Management, 27(7-8), 808833. 